As-Syifaa Jurnal Farmasi Desember 2020;12(2):158-163.

ISSN : 2502-9444 (electronic); 2085-4714 (printed)

Journal Homepage : http://jurnal.farmasi.umi.ac.id/index.php/as-syifaa

\title{
UJI AKTIVITAS EKSTRAK ETIL ASETAT DAUN KAYU JAWA (Lannea coromandelic (Houtt.) Merr.) TERHADAP PENYEMBUHAN LUKA BAKAR PADA TIKUS PUTIH (Rattus norvegicus)
}

\author{
Bayu Putra, Safriani Rahman
}

Fakultas Farmasi Universitas Muslim Indonesia Makassar

Email: bayu.putra@umi.ac.id

\begin{abstract}
Wound healing is a process of repairing skin and soft tissue when these organs are injured. One of the plants that are presumed to affect wound healing is Kayu Jawa (Lannea coromandelic (Houtt.) Merr.). This research aims to determine the healing effect of burns and the effective dose of ethyl acetate extract of Kayu Jawa's leaves. The animal test that has been induced using a hot plate with temperature $100 \circ \mathrm{C}$ stuck at the back of mice were divided into 5 (five) groups. Group $1 \mathrm{Na}$.CMC as Negative control, Group 2 Lanakeloid-E as Positive control, Group III, IV, and V were extract ethyl acetate of Kayu Jawa's leaves (Lannea coromandelic (Houtt.) Merr) with 3 dosage variations namely, $75 \mathrm{mg} / \mathrm{kg}, 150 \mathrm{mg} / \mathrm{kg}$, and $300 \mathrm{mg} / \mathrm{kg}$ were given topically 2 times a day for 21 days. Then wound area measure using calipers. The group with $300 \mathrm{mg} / \mathrm{kg}$ dosage has the best effect for reducing wound area of burns, with statistical value not significantly different from the comparison group (Lanakeloid-E) with a percentage value of $84 \%$.
\end{abstract}

Key word: Wound healing, ethyl acetate, Lannea coromandelic (Houtt.) Merr), Rattus norvegicus.

\section{PENDAHULUAN}

Luka didefinisikan sebagai suatu keadaan kehilangan atau kerusakan kontinu sebagian dari jaringan tubuh ditandai dengan hilangnya substansi jaringan yang disebabkan adanya faktor-faktor yang mengganggu sistem perlindungan tubuh. ${ }^{1}$ Faktor-faktor yang dimaksud dapat berupa trauma benda tajam atau tumpul, perubahan suhu, zat kimia, ledakan, sengatan listrik atau gigitan hewan. ${ }^{2}$

Bentuk umum dari luka sangat bervariasi tergantung dari penyebabnya yaitu luka terbuka dan tertutup. Salah satu contoh luka terbuka adalah luka akut yang merupakan bentuk dari kerusakan jaringan yang dapat pulih kembali normal dalam rentang waktu tertentu. Luka akut biasa terjadi akibat adanya cedera mekanikal karena faktor eksternal seperti terjadinya kontak antara kulit dengan permukaan yang keras atau tajam, luka tembak, dan luka pasca operasi. Penyebab lain luka akut adalah luka bakar dan cedera kimiawi, seperti terpapar sinar radiasi, tersengat listrik, terkena cairan kimia yang besifat korosif, serta terkena sumber panas. ${ }^{3,4}$

Penyembuhan luka merupakan suatu proses perbaikan kulit dan jaringan lunak ketika organ tersebut mengalami cedera. Terdapat beberapa respons yang mencetuskan tejadinya proses tersebut seperti peradangan dan peningkatan produksi kolagen (jaringan ikat) sel-sel di bawah dermis. Kemudian, jaringan epitel (kulit luar) diregenerasi. Ada beberapa tahapan penyembuhan luka seperti peradangan, proliferasi, dan remodeling. ${ }^{5}$

Pada dasarnya pengobatan untuk menyembuhkan luka sudah banyak digunakan oleh masyarakat umum dan memiliki keamanan dan efektifitas yang baik, apabila penggunaannya dalam dosis yang sesuai. 
Uji Aktivitas Ekstrak Etil Asetat Daun Kayu Jawa (Lannea coromandelic (Houtt.) Merr.) Terhadap Penyembuhan Luka Bakar Pada Tikus Putih (Rattus norvegicus)

Pengobatan terhadap luka dapat dilakukan dengan beberapa cara, diantaranya secara medis dan empiris. Pengobatan secara medis biasanya menggunakan bahan-bahan kimia efektif dapat menghambat dan membunuh mikroba, namun bahan-bahan tersebut dapat menimbulkan iritasi pada kulit, reaksi alergi, residu, toksik pada sel infeksi baru yang harus diobati dengan obat yang lebih paten dan harga mahal bahkan dapat menimbulkan resistensi dari mikroba. ${ }^{6}$ Oleh karena itu diperlukan terapi alternatif dengan menggunakan bahan empiris dari alam sehingga masyarakat beralih kembali pengobatan tradisional yang lebih murah.

Salah satu tanaman yang diduga dapat memberikan efek penyembuhan luka adalah tanaman kayu jawa (Lannea coromandelic (Houtt.) Merr.). ${ }^{7}$ Tanaman ini banyak tumbuh di Indonesia khusunya di Sulawesi Selatan. Biasanya, kayu jawa (Lannea coromandelic (Houtt.) Merr.) atau dalam bahasa Makassar disebut kayu tammate, bugis disebut aju jawa masih digunakan oleh masyarakat sebagai pagar dan bahan bakar dalam rumah tangga. Selain itu, secara empiris tanaman ini biasa digunakan oleh masyarakat untuk pengobatan seperti getahnya sebagai penyembuhan luka, daunnya untuk mengobati pembengkakan akibat keseleo, dan korteks kayu jawa sebagai antiinflamasi, antimitosis dan antioksidan. .,9,10 $^{2}$

Kayu jawa (Lannea coromandelic (Houtt.) Merr.) mengandung komponen kimia berupa flavonoid, karbohidrat, getah gum, mucilago, tannin, saponin dan terpenoid. ${ }^{11,12}$ Komponen kimia inilah yang memiliki kemungkinan dapat memberikan efek penyembuhan luka. Menurut Soni and Soni and Singhai (2012) menyatakan bahwa senyawa tanin berperan sebagai astringent pada luka sedangkan saponin bekerja meningkatkan kecepatan epitelisasi. ${ }^{13}$ Senyawa flavonoid berperan dalam penyembuhan luka dengan menghentikan perdarahan yaitu melalui mekanisme vasokontriksi pada pembuluh darah, penangkal radikal bebas, penghambat hidrolisis dan oksidasi enzim, serta bersifat antiinflamasi.

Beberapa penelitian sebelumnya telah melaporkan bahwa ekstrak metanol kulit batang Kayu Jawa memiliki aktivitas biologis seperti antibakteri, antioksidan, analgesik, aktivitas hipotensia, aktivitas penyembuhan luka. ${ }^{7}$ Ismail et al. (2016) menyatakan bahwa ekstrak metanol dan ekstrak n-heksan kortex Kayu Jawa (Lannea coromandelica (Houtt.) Merr.) dapat menghambat pertumbuhan bakteri Escherichia coli, Pseudomonas aeruginosa, dan Salmonella thypi. ${ }^{14}$ Selain itu, penenitian sebelumnya menyebutkan bahwa penggunaan ekstrak etanol daun kayu jawa dengan dosis 75 $\mathrm{mg} / \mathrm{kgBB}, 150 \mathrm{mg} / \mathrm{kgBB}$, dan $300 \mathrm{mg} / \mathrm{kgBB}$ memiliki potensi sebagai antiinflamasi yang diujikan pada tikus (Rattus norvegicus). ${ }^{15}$

\section{METODE KERJA}

\section{Pembuatan Ekstrak Etil Asetat}

Ekstrak etil asetat daun kayu jawa dibuat dengan metode maserasi sampel daun dimasukkan dalam wadah maserasi kemudian ditambahkan pelarut etil asetat hingga simplisia terendam sempurna, dibiarkan selama 1×24 jam dalam bejana tertutup dan terlindung dari cahaya sambil sesekali diaduk. ${ }^{16,17}$

\section{Pembuatan larutan uji}

Ekstrak etil asetat daun kayu jawa dibuat dalam 3 dosis yaitu $75 \mathrm{mg} / \mathrm{kgbb}, 150$ $\mathrm{mg} / \mathrm{kgbb}$, dan $300 \mathrm{mg} / \mathrm{kgbb}$. Untuk membuat dosis $75 \mathrm{mg} / \mathrm{kgbb}$ yaitu ditimbang sebanyak $150 \mathrm{mg}$ (15 mg/200 gr tikus) kemudian di larutkan dalam $20 \mathrm{~mL} \mathrm{NaCMC} 1 \%$ b/v sebagai larutan stok obat. Untuk membuat dosis 150 
Uji Aktivitas Ekstrak Etil Asetat Daun Kayu Jawa (Lannea coromandelic (Houtt.) Merr.) Terhadap Penyembuhan Luka Bakar Pada Tikus Putih (Rattus norvegicus)

$\mathrm{mg} / \mathrm{kgbb}$ dan $300 \mathrm{mg} / \mathrm{kgbb}$ masing-masing ditimbang $300 \mathrm{mg}$ dan $600 \mathrm{mg}$ yang dilarutkan dalam $20 \mathrm{~mL} \mathrm{NaCMC} \mathrm{1 \%} \mathrm{b/v.}$

\section{Perlakuan Hewan Uji}

Punggung tikus putih yang telah dicukur bulunya, dibersihkan dengan alkohol dan dianastesi menggunakan $0,2 \mathrm{~mL}$ ketamin secara intraperitoneal. Kemudian diinduksi luka bakar menggunakan plat panas dengan suhu $100^{\circ} \mathrm{C}$ dan ditempelkan pada kulit punggung tikus putih selama 2 detik sampai terbentuk luka bakar. Hewan uji dibagi ke dalam 5 kelompok. Kelompok I sebagai kelompok kontrol negatif, kelompok II sebagai kontrol positif, kelompok III, IV, dan V adalah ekstrak etil asetat daun kayu jawa (Lannea coromandelic (Houtt.) Merr) dengan 3 variasi konsentrasi yaitu $75 \mathrm{mg} / \mathrm{kgbb}, 150 \mathrm{mg} / \mathrm{kgbb}$, dan $300 \mathrm{mg} / \mathrm{kgbb}$. Sediaan uji diberikan secara topikal $2 x$ sehari selama 21 hari. Kemudian dilakukan pengukuran terhadap luas permukaan luka menggunakan jangka sorong. Pengukuran dan pengamatan luas permukaan luka pada hari ke-3, $-5,-7,-14$, dan $-21 .^{18}$

\section{HASIL DAN PEMBAHASAN}

Tabel 1. Rata-rata penurunan luas permukaan luka pada kulit punggung tikus putih (Rattus norvegicus) yang diinduksi dengan plat panas.

\begin{tabular}{lcccccc}
\hline \multirow{2}{*}{ Perlakuan } & $\begin{array}{c}\text { Induksi } \\
\text { (cm) }\end{array}$ & \multicolumn{5}{c}{ Rata-rata luas permukaan luka setelah hari ke- $\left(\mathbf{c m}^{2}\right) \pm$ SD } \\
\cline { 3 - 7 } & $\mathbf{3}$ & $\mathbf{5}$ & $\mathbf{7}$ & $\mathbf{1 4}$ & $\mathbf{2 1}$ \\
\hline $\begin{array}{l}\text { Kontrol } \\
\text { negatif }\end{array}$ & 4 & $5,905 \pm 0,639$ & $5,560 \pm 0,768$ & $4,965 \pm 0,829$ & $3,368 \pm 0,599$ & $1,977 \pm 0,330$ \\
EEADKJ 75 & 4 & $5,639 \pm 0,901$ & $5.257 \pm 0,730$ & $4,877 \pm 0,961$ & $3,242 \pm 0,886$ & $1,648 \pm 0,236$ \\
mg/kgBB & & & & & & \\
EEADKJ 150 & 4 & $5,658 \pm 0,548$ & $4,885 \pm 0,698$ & $4,312 \pm 0,918$ & $3,108 \pm 0,660$ & $1,844 \pm 0,851$ \\
mg/kgBB & & & & & \\
EEADKJ 300 & 4 & $5,592 \pm 0,939$ & $4,067 \pm 0,777$ & $3,105 \pm 1,060$ & $2,695 \pm 0,490$ & $0,632 \pm 0,399$ \\
mg/kgBB & 4 & $5,862 \pm 0,170$ & $3,970 \pm 0,588$ & $1,918 \pm 0,645$ & $0,876 \pm 0,696$ & $0,368 \pm 0,765$ \\
\hline Kontrol positif & 4 & & & & &
\end{tabular}

Tabel 2. Persentase penurunan luas permukaan ekstrak etil asetat daun kayu jawa (Lannea coromandelic (Houtt.) Merr.) terhadap tikus putih (Rattus norvegicus)

\begin{tabular}{cc}
\hline Kelompok Perlakuan & Persen Penurunan Luka (\%) \\
\hline Kontrol negatif & 51 \\
EEADKJ $75 \mathrm{mg} / \mathrm{kgBB}$ & 54 \\
EEADKJ $150 \mathrm{mg} / \mathrm{kgBB}$ & 59 \\
EEADKJ $300 \mathrm{mg} / \mathrm{kgBB}$ & 84 \\
Kontrol positif & 90 \\
\hline Ket: EEADKJ (Ekstrak Etil Asetat Daun Kayu Jawa) &
\end{tabular}

Ket: EEADKJ (Ekstrak Etil Asetat Daun Kayu Jawa)

Pada penelitian ini telah dilakukan uji aktivitas ekstrak etil asetat daun kayu jawa (Lannea coromandelic (Houtt.) Merr.) terhadap penyembuhan luka bakar pada tikus putih (Rattus norvegicus). Tujuan penelitian ini yaitu dapat menentukan efek penyembuhan luka bakar dari sampel uji dan memperoleh dosis efektif yang dapat memberikan efek penyembuhan pada hewan coba yang digunakan. Penentuan aktivitas efek penyembuhan luka bakar ekstrak etil asetat daun kayu jawa dilakukan dengan cara mengukur luas permukaan luka menggunakan jangka sorong yang sebelumnya diinduksi plat panas dengan suhu $100^{\circ} \mathrm{C}$ selama 2 detik sehingga terbentuk luka. Metode ini digunakan 
Uji Aktivitas Ekstrak Etil Asetat Daun Kayu Jawa (Lannea coromandelic (Houtt.) Merr.) Terhadap Penyembuhan Luka Bakar Pada Tikus Putih (Rattus norvegicus)

karena lebih sederhana, cepat dan hasil pengukuran yang diperoleh cukup akurat.

Sampel yang digunakan dalam penelitian ini adalah ekstrak etil asetat daun kayu jawa (EEADKJ). Ekstrak diperoleh melalui proses maserasi dengan menggunakan pelarut etil asetat. Untuk melihat kemampuan EEADKJ sebagai bahan penyembuhan luka bakar, maka sampel diujikan pada hewan coba tikus. Hewan uji dibagi kedalam 5 kelompok yang terdiri dari kelompok kontrol (diberikan Na.CMC 1\%), kelompok perlakuan (EEADKJ dosis 75 $\mathrm{mg} / \mathrm{kgBB}, 150 \mathrm{mg} / \mathrm{kgBB}$, dan $300 \mathrm{mg} / \mathrm{kgBB}$ ), dan kelompok pembanding (Lanakeloid-E). Penginduksian luka bakar dilakukan dengan menggunakan plat panas suhu $100^{\circ} \mathrm{C}$ dengan meletakkan termometer hingga menyentuh plat, penginduksian dilakukan selama 2 detik bagian kulit punggung tikus. Sediaan uji baik kontrol positif maupun sampel EEADKJ dengan berbagai konsentrasi diberikan secara topikal sebanyak 2 kali sehari selama 21 hari. Sediaan uji diberikan secara topikal karena dapat memberikan efek lokal, sehingga proses penyembuhan luka akan lebih cepat. Pemberian sediaan uji dilakukan 2 kali sehari dikarenakan mengikuti aturan pakai atau penggunaan dari kontrol positif yang digunakan. Pemberian sediaan uji dan kontrol dilakukan selama 21 hari dikarenakan proses penyembuhan luka bakar selama rentan waktu 3-9 minggu. ${ }^{19}$ Selain itu, penelitian ini menggunakan krim Lanakeloid-E sebagai kontrol positif berdasarkan pada indikasi sediaan kontrol yang dapat membantu proses penyembuhan luka bakar. Selain itu, pada penelitian yang telah dilakukan oleh Rahim et al., (2011) melaporkan bahwa sampel ini telah menyembuhkan luka bakar paddalam waktu 8 hari dengan metode pembuatan luka bakar yang berbeda. ${ }^{20}$ Pada tabel 1 memperlihatkan rata-rata penurunan luas permukaan luka punggung tikus setelah diinduksi menggunakan plat panas $100^{\circ} \mathrm{C}$. Pada tabel tersebut menunjukkan bahwa semua kelompok memperlihatkan penurunan luas luka pada tiap hari pengukuran dari hari ke-3,5,7,14 dan 21 . Rata-rata penurunan luas luka pada semua kelompok uji mengalami perubahan mulai hari ke-3 sampai 21. Untuk melihat besarnya aktivitas penurunan luas luka tiap kelompok maka data pada tabel 1 dihitung persen penurunan yang dapat dilihat pada tabel 2 .

Berdasarkan tabel 2, dapat dilihat bahwa kelompok perlakuan EEADKJ memperlihatkan adanya penurunan luka punggung tikus yang sangat baik jika dibandingkan dengan kelompok kontrol negatif (Na.CMC) yaitu 54-84\%, namun EEADKJ dosis $300 \mathrm{mg} / \mathrm{kgBB}$ memberikan persen penurunan yang lebih besar jika dibandingkan dengan 2 varian dosis EEADKJ lainnya. Sedangkan kelompok kontrol negatif (Na.CMC) mengalami rata-rata persentase penurunan luka sebesar $51 \%$.

Berdasarkan data persen penurunan luas permukaan luka dan analisa statistik diketahui bahwa ekstrak ini memiliki kemampuan mempercepat proses penyembuhan luka bakar. Kemampuan tersebut diduga karena adanya beberapa kandungan senyawa kimia seperti glikosida, flavonoid, dan steroid-triterpenoid dalam ekstrak. ${ }^{11}$ Kandungan kimia flavonoid dan steroid triterpenoid diduga dapat memberikan efek sebagai agen antiinflamasi, antioksidan, mencegah terjadinya penyumbatan pada pembuluh darah, melancarkan peredaran darah ke seluruh tubuh, serta membantu mengurangi rasa sakit jika terjadi 
Uji Aktivitas Ekstrak Etil Asetat Daun Kayu Jawa (Lannea coromandelic (Houtt.) Merr.) Terhadap Penyembuhan Luka Bakar Pada Tikus Putih (Rattus norvegicus)

pembengkakan atau perdarahan. ${ }^{21}$ Flavonoid juga berperan sebagai antimikroba yang dapat mempercepat proses penyembuhan luka. ${ }^{22}$ Selain itu flavonoid dapat merangsang pelepasan sel-sel fibroblast yang dapat mempercepat proses epitelisasi.

Kandungan tanin berfungsi sebagai adstringen yang dapat mengecilkan pori-pori kulit, menghentikan eksudat dan pendarahan ringan. ${ }^{23}$ Senyawa tanin mengandung senyawa antibakteri dimana senyawa tersebut membantu mengkerutkan dinding sel atau membran sel sehingga menghambat permeabilitas bakteri untuk berkembang. ${ }^{24}$

\section{KESIMPULAN}

Dari hasil penelitian menunjukkan bahwa semua kelompok pengujian ekstrak etil asetat daun kayu jawa dengan dosis 75 $\mathrm{mg} / \mathrm{kgBB}$, $150 \mathrm{mg} / \mathrm{kgBB}$, dan $300 \mathrm{mg} / \mathrm{kgBB}$ memiliki potensi menurunkan luas permukaan luka bakar pada tikus putih dan dosis 300 $\mathrm{mg} / \mathrm{kgBB}$ memiliki efek yang paling baik dalam menurunkan luas permukaan luka bakar serta memiliki nilai statistik tidak berbeda nyata dengan kelompok pembanding (Lanakeloid-E).

\section{DAFTAR PUSTAKA}

1. Mansjoer A, Wardhani WI, Setiowulan W, Triyanti K, and Savitri R. Kapita Selekta Kedokteran Edisi Tiga. Jakarta. Mediaesculapius, 2000

2. Sjamsuhidajat R and Dejong W. Buku Ajar: Ilmu Bedah. Jakarta. EGC., 2005.

3. Baxter C. The Normal Healing Process. In: New Directions in Wound Healing. NJ: E.R. Squlbb \& Sons, Inc. Princeton. 1990.

4. Purnama H, Sriwidodo, Mita SR. Proses Penyembuhan dan Perawatan Luka: Review Sistematik. Farmaka. 2017;15(2): 251-258.

5. Garg VK, and Paliwal SK. Wound-Healing Activity of Ethanolic And Aqueous Extracts of Ficus benghalensis. J Adv Pharm Technol Res. 2011;2(2):110-114.
6. Ismail. Luka dan Perawatannya. 2008. http://images.mailmkes.multiplymultiplycon tent.com. Diakses tanggal 1 Juni 2019. Pukul 12.30 WITA.

7. Alam MB, Kwon KR, Lee SH, Lee SH. Lannea coromandelica (Houtt.) Merr. Induces Heme Oxygenase 1 (HO-1) Expression and Reduces Oxidative Stress via the p38/c-Jun N-Terminal KinaseNuclear Factor Erythroid 2-Related Factor 2 (p38/JNK-NRF2)-Mediated Antioxidant Pathway. Int J Mol Sci. 2017;18(2): 266.

8. Rahayu, Sunarti S, Diah P, Suhardjono. Pemanfaatan tanaman obat secara tradisional oleh masyarakat lokal di pulau wawoni. Sulawesi tenggara. Jurnal Biodersivitas. 2006 ;(7)3.

9. Rahmadani F. Uji Aktivitas Antibakteri Dari Ekstrak Etanol 96\% Kulit Batang Kayu Jawa (Lannea coromandelica) Terhadap Bakteri Staphylococcus aureus, Escherichia coli, Helicobacter pylori, Pseudomonas aeruginosa (Skripsi). Jakarta. Fakultas Kedokteran Dan IImu Kesehatan. UIN Syarif Hidayatullah. 2015

10. Saputra A. Uji Aktivitas Antiinflamasi Ekstrak Etanol 96 \% Kulit Batang Kayu Jawa (Lannea coromandelica) dengan Metode Stabilitas Membrane Sel Darah Merah Secara In Vitro (Skripsi). Jakarta. Fakultas Kedokteran Dan IImu Kesehatan. UIN Syarif Hidayatullah. 2015.

11. Manik MA, Wahid SMA, Islam A, Pal KT, Ahmed. A Comparative Study of the Antioxidant, Antimicrobial and Thrombolytic Activity of the Bark and Leaves of Lannea coromandelica (Anacardiaceae). International Journal of Pharmaceutical Sciences and Research. 2013;4(7): 2609-2614.

12. Stalin JD, Babu DT, and Kumar SS. A Study on the Antioxidant and Free Radical Scavenging Property of Lannea Coromandelica Bark Extract. International Journal of Universal Pharmacy and Life Sciences. 2013;3(5), 2249-6793.

13. Soni $H$ and Singhai AK. A Recent Update of Botanicals for Wound Healing Activity. International Research Journal of Pharmacy. 2012;3(7):1-7. 
14. Ismail I, Paturusi AAE, Aridani I. Aktivitas Antimikroba Hasil Fraksinasi Kortex Kayu Jawa (Lannea coromandelica (Houtt.) Merr.). Biogenesis. 2016;4(2):122-130.

15. Putra B and Rahman S. Pengaruh Dosis Ekstrak Etanol Daun Kayu Jawa (Lannea coromandelic (Houtt.) Merr.) Terhadap Aktivitas Antiinflamasi Pada Tikus (Rattus norvegicus). As-Syifaa J Farm. 2019;11(2):131-136.

16. Dirjen POM. Sediaan Galenik. Jakarta Departemen Kesehatan Republik Indonesia., 1986.

17. Ditjen POM. Farmakope Indonesia Edisi V. Jakarta. Departemen Kesehatan Republik Indonesia. 2004.

18. Marison MJ. Manajemen Luka. Jakarta.Penerbit Buku Kedokteran EGC. 2004.

19. Alqahtani SM, Alzahrani MM, Carli A, and Harvey EJ. Burn Management in Orthopaedic Trauma. Journal of bone and joint surgery, incorporated. 2014;2(10): 4
20. Rahim F, Mimi A, Nurwani PA. Formulasi krim ekstrak etanol daun ubi jalar (Ipomea batatas L.) untuk pengobatan luka bakar. Scientia Jurnal Farmasi dan Kesehatan. 2011;1(1):21-26.

21. Wahyuningsih S. Soemardji $A A$ and Febiyanti D. Efek Gel Lidah Buaya (Aloe barbadensis Mill) Terhadap Penyembuhan Luka Bakar Eksperimen Pada Tikus Wister Betina. Prosiding seminar nasional tumbuhan obat indonesia XXIX. 2006.

22. Ambiga SR, Narayanan D, Gowri D, Sukumar D, Madhavan S. Evaluation of Wound Healing Activity ofFlavonoids from Ipommoea carne Jacq. Ancient Science of Life. 2007;26(3):45-51.

23. Anief M. Formulasi Obat Topikal Dengan Dasar Penyakit Kulit. Yogyakarta. Gajah Mada University Press.1997.

24. Ajizah A. Sensitivitas Salmonella typhimurium terhadap Ekstrak Daun Psidium Guajava L. Bioscientie. 2004.1 (1): 31-38. 